\title{
THE USE OF WRF MODEL TO SUPPORT CLOUD SEEDING OPERATION: A STUDY IN THE CITARUM CATCHMENT AREA
}

\author{
Mahally Kudsy, Ridwan, Findy Renggono, Faisal Sunarto
}

\begin{abstract}
This paper presents about the use of WRF modelling to assist weather analysis for cloud seeding operation in the Citarum Catchment Area, West Java, Indonesia. In this study, WRF parameterization was carried out. The parameterized values were used to forecast precipitation during cloud seeding operation. To study the effect of variational run, WRF 3DVAR was run using GDAS data set and doppler weather radar data. The result of this study shows that precipitation can be better predicted by ingesting radar data into 3DVAR run.
\end{abstract}

\section{Intisari}

Makalah ini menyajikan tentang penggunaan pemodelan dengan WRF untuk membantu analisis cuaca yang dipakai dalam operasi penyemaian awan di DAS Citarum, Jawa Barat, Indonesia. Dalam kajian ini telah dilakukan parameterisasi WRF, kemudian nilai parameter yang diperoleh dipakai untuk mendapatkan prakiraan presipitasi selama operasi penyemaian awan. Untuk mempelajari pengaruh dari run variasional, WRF 3DVAR dijalankan dengan menggunakan data GDAS dan data radar doppler. Hasil dari studi ini menunjukkan bahwa prakiraan presipitasi yang lebih baik dapat diperoleh dengan mengasimilasikan data radar ke dalam run 3DVAR.

Kata kunci : $\quad$ WRF Model, parameterisasi, prediksi presipitasi, 3dvar

\section{INTRODUCTION}

The Citarum Catchments Area is a very important area in Indonesia because it provides water for rice irrigation and hydropower generation. Its total area covers more then $7000 \mathrm{~km}^{2}$. There are 3 cascaded hydropower dams that supply $6000 \mathrm{MW}$ electricity and rice field that produce about $30 \%$ of national production (Figure-1).

Due to its strategic value, Indonesian Government and related authorities have conducted many short-termed cloud seeding programs to ensure the provision of water supply for this area. WMTU has conducted 76-months cloud seeding operations since 1980. This year, WMTU has conducted 30 days operation during 18 March- 8 April 2011.

Weather predictability is very important in cloud seeding operation, this can be achieved if atmospheric measurement can be conducted. In case of instrumentation lack, some efforts must be made to obtain the likely atmospheric condition. Models such as WRF can be used to forecast near future atmosphere properties. We have used

\footnotetext{
1 Perekayasa Madya - UPT Hujan Buatan, BPPT, Thamrin No. 8 Jakarta, email: mkudsy@gmail.com
}

WRF to study weather seedability during the period mentioned above.

WMTU has operated C-band Doppler weather radar for several years. It is desired that radar can be used to optimize the operation economy by data assimilation into WRF prediction runs. WRF has potential use in cloud seeding such as mentioned by several workers (Peckham et.al, 2008; Stone, et.al, 2009). The use of model is very helpful to remove some uncertainties during cloud seeding operation (Levin et.al, 1997).

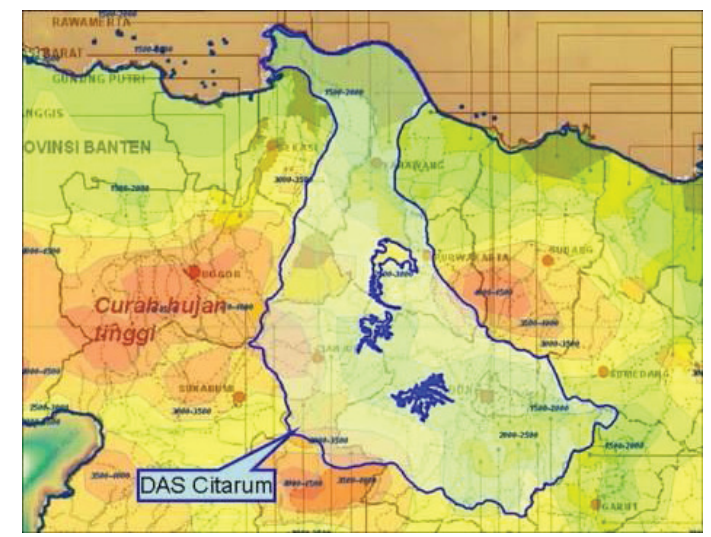

Figure 1. The Citarum Catchment Area with 3-cascaded dams 
This paper presents the result our first attempt to utilize model in cloud seeding. First, WRF physics parameterization was conducted to obtain correct physical parameters, namely microphysical and cumulus parameters. Subsequently, these parameters were used to forecast rain precipitation within a selected period. Then, WRF 3DVAR was employed using GDAS data set. Finally Doppler weather radar data was ingested into 3DVAR WRF runs. Comparisons of observed and forecast values are reported here.

\section{METHOD}

First, WRF was run using freely available GFS data set obtained from NCAR to generate a 3-day forecast within the domain bounded by (5S$9 \mathrm{~S}, 105 \mathrm{E}-112 \mathrm{E}$ ). This domain is much larger in size than the actual area of cloud seeding operation. To obtain the desirable parameters, WRF was run to forecast precipitation of the area outside the cloud seeding period. by varying the microphysics (mp_physics $=3,4,6,8$ ) and cumulus parameters (cu_physics $=0,1,2,3,5$ ). The output of WRF was analyzed for precipitation amount.

Analyses results indicates that for $\mathrm{mp}_{-}$ physics for this domain does not have strong influence on precipitation, which is contrast to the cumulus parameter. The best cumulus parameter for this study is 5 . Table 1 shows the explanation of the parameters studied.

Table 1. Microphysical and cumulus parameters investigated in this study

\begin{tabular}{|c|c|c|c|}
\hline \multicolumn{2}{|c|}{ Microphysics } & \multicolumn{2}{c|}{ Cumulus } \\
\hline value & scheme & value & scheme \\
\hline & & 0 & No cumulus \\
\hline 3 & WRF-SM3 & 1 & Kain-Fristch \\
\hline 4 & WRF-SM5 & 2 & $\begin{array}{c}\text { Bets-Miller- } \\
\text { Janjic }\end{array}$ \\
\hline 6 & WRF-SM6 & 3 & Grell-Devenyi \\
\hline 8 & New Thompson & 5 & 3D-Grell \\
\hline
\end{tabular}

The parameters (cu_physics and $\mathrm{mp}$ physics) which produced the best patterns were used in WRF to predict 3 days condition (24-26 May 2011). Precipitation data obtained from 10 rain gages were compared with observed data and compared using point analysis.
WRF variation runs (WRF3DVAR) were made using observational data GDAS data set using PREPBUFR format from NCEP. GDAS data set used in this prediction was taken at the model initialization time (without data update). Finally, for the purpose to improving the results of the prediction, WRF 3DVAR was run using Doppler weather data. During cloud seeding period a mobile doppler radar was operated to help locate potentially seedable clouds. The radar data volume itself is very large, so it needs a series of selection and thinning proces before it can be ingested into 3DVAR.

\section{RESULTS AND DISCUSSION}

WRF accommodates a large number of parameterization. Previous studies such as Nepal's study (Regmi, et.al 2011), suggested that parameterization can often be successfully made by directly targeting to the specific problem.

Figure 3 shows that there is no significant in precipitation pattern from WRF output by varying microphysics parameter. Thus subsequent WRF runs were then made by using mp_physics $=5$. This parameter has been used in operation forecasting by NCEP, where the scheme considers a mixed phase processes.

Physical cumulus parameterization in WRF has developed from simple to advanced scheme. Now there are 6 cumulus schemes have been introduced. In general, where grid size is larger than cumulus' scale, WRF is often run without considering $\mathrm{Cu}(\mathrm{Cu}=0)$. In this study cu_physics $=5$ is relatively better than other values, as can be seen in Figure 3.

The results of precipitation prediction from WRF output can be seen in Figure-4. The results were taken from a 3-day forecast (March 24$26,2011)$. The results are compared with observed values from 9 rain gauges within cloud seeding operation area.

The effect of data assimilation using GDAS and assimilation with Doppler weather radar are presented here for comparison. Although WRF 3DVAR is run, the result nearer to the model initial will give the best result. The longer the difference to the initial time, more spurious error will be expected from the result. Figure 4 show the comparison of observed values (OBS), WRF control run without assimilation (CNTL), run with GDAS assimilation (GDAS), and run with GDAS and Doppler weather radar assimilation (GDAS+DWR) for March 24. 
Jabar-Jateng Rainfall Forecast Valid_for_UTC_O320.5MAY2011 (in mm)
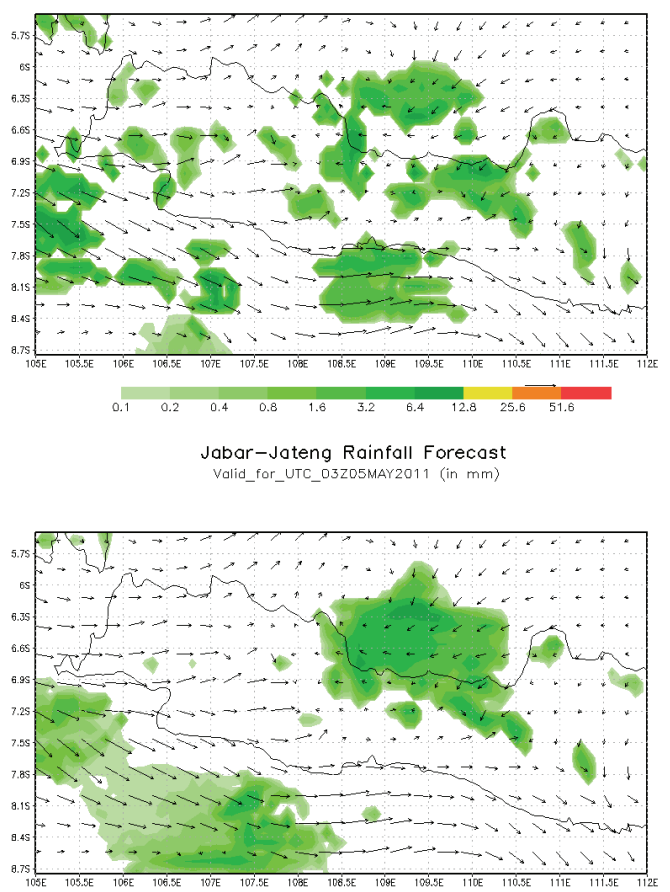

$\begin{array}{llllllllll}0.1 & 0.2 & 0.4 & 0.8 & 1.6 & 3.2 & 0.4 & 12.8 & 25.6 & 51.6\end{array}$

Jabor-Jateng Rainfall Forecost

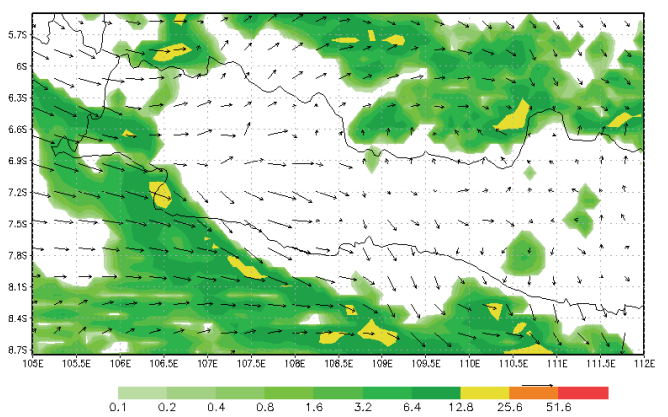

Jabar-Joteng Rainfall Forecost valid_for_UTL_O3ZOSMAY2O11 (in mm)
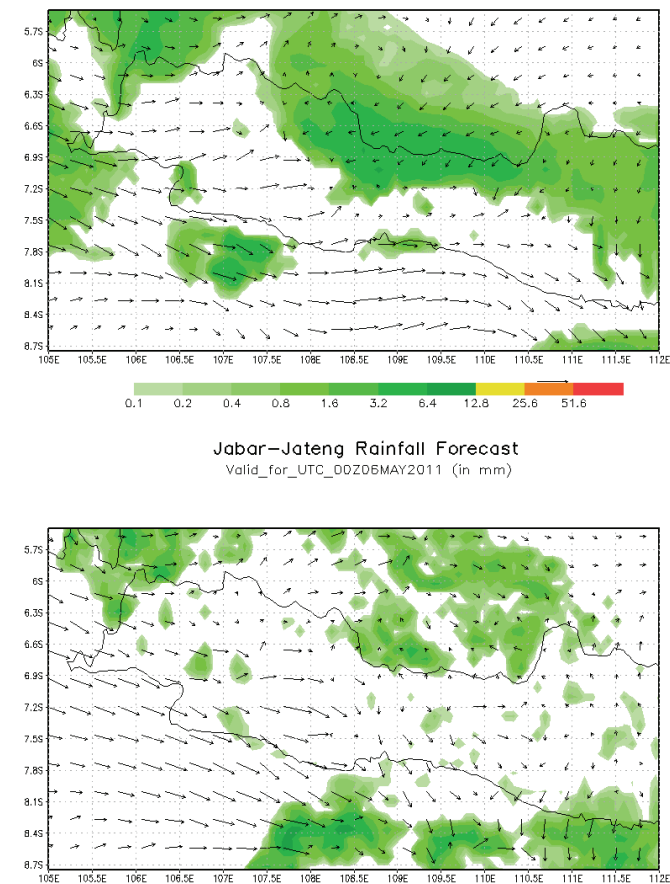

$\begin{array}{lllllllllll}0.1 & 0.2 & 0.4 & 0.8 & 1.6 & 3.2 & 6.4 & 12.8 & 25.6 & 51.6\end{array}$
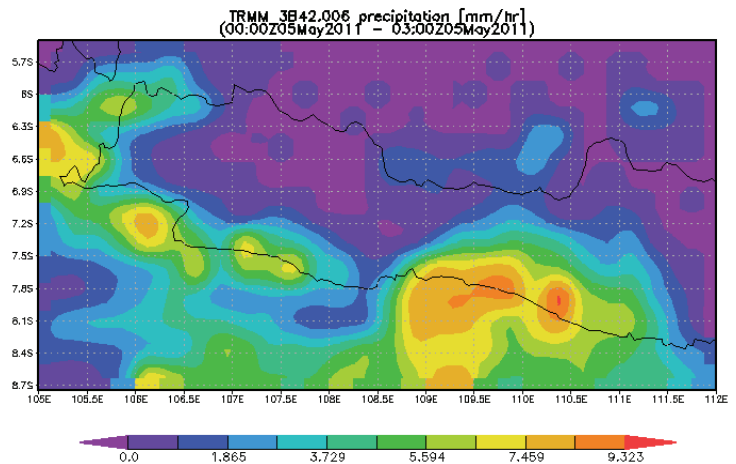

Figure-2. Sample from WRF preciptation output

\section{CONCLUSION AND REMARKS}

Observable precipitation increase (or decrease) is the main objective in cloud seeding works. Therefore the predictability of precipitation will to extent remove some uncertainty of the result. It is shown from the present study that precipitation can be relatively to some extent accurately predicted.

WRF run can produce precipitation. Using GFS data it can forecast precipitation $72 \mathrm{hr}$ - ahead. The accuracy of prediction can be increased by running GDAS data and doppler data ingestion.

There are many indicators that are usually used to predict the atmospheric condition, namely $\mathrm{K}$ index, Sweat Index, Index of Coalescence Activity (ICA). In the absence of measurement, it is impossible to measure or calculate these indices, while they are very handy indicators for cloud seeding operation. However, with a reliable forecast product, such indices can be easily approximated. . According author's study from published papers ICA is one of the best indicators to predict air seedability.

\section{ACKNOWLEDGEMENT}

This paper constitutes a partial report to The Ministry of Research and Technology for their funding support through The Research Incentive Program 2011; and to Weather Modification Technical Services through Global Warming Mitigation Program - 2011. 


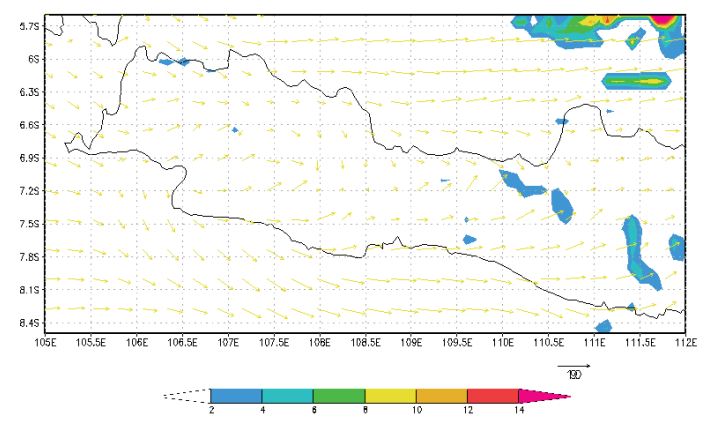

Curah Hujan Jabar-Jateng WRF (Opsi mp4) Valid_for_UTC_03ZO1FEB201

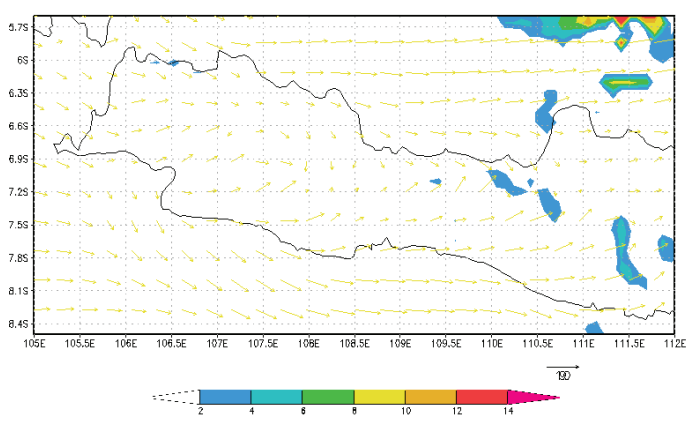

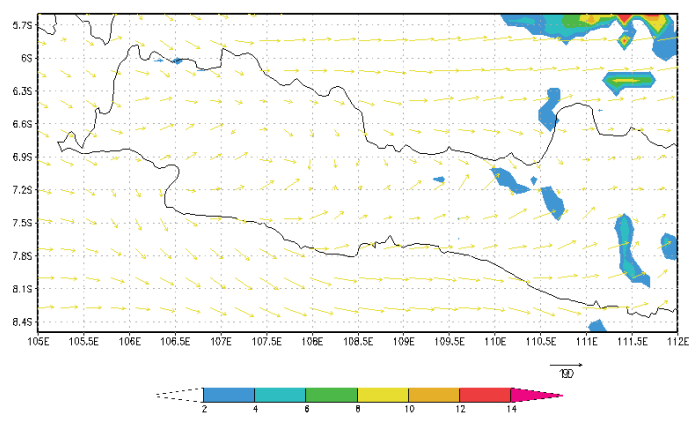

Curah Hujan Jabar-Jateng WRF (Opsi mp8) alli_for_UTC_0.3Z01FEB2011

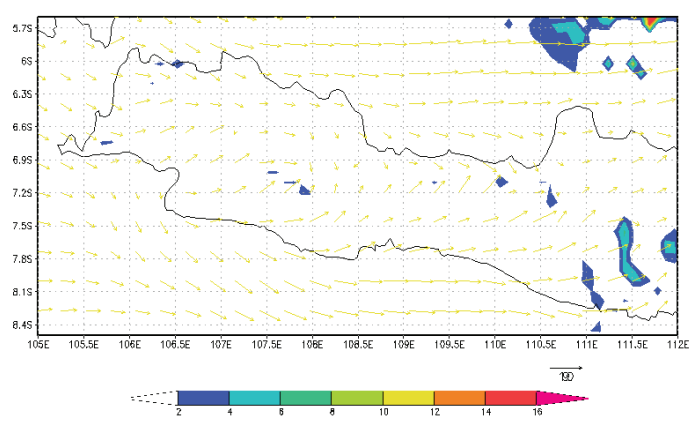

Figure 3: Effect of microphysical parameter on precipitation in WRF

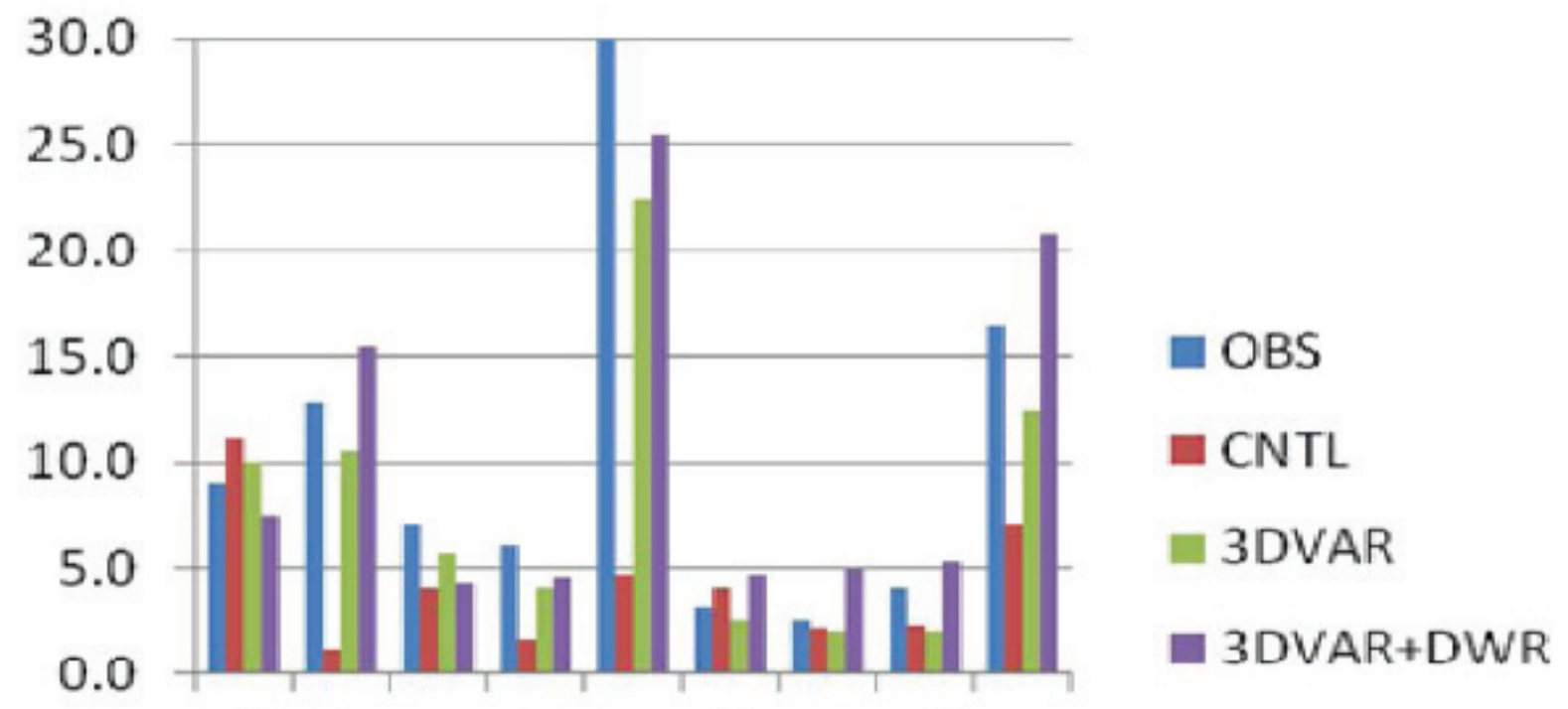

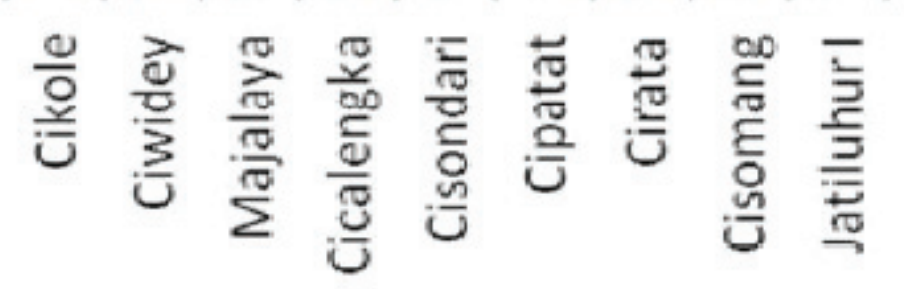

Figure 4: Precipitation comparison of observed, control, 3DVAR with GDAS, and 3DVAR with radar data ingestion 


\section{REFERENCES}

Levin, Zev, Shimon, O. Krichak, and Tamir Reisin. Numerical simulation of dispersal of inert seeding material in israel using a three dimensional mesoscale model. J. Appl. 36, 474-484, 1997

Murali-Krishna , I. V. and Manickam, V., Global Climatic Change And Weather Modification Technologies, 760pp BS Publicatons Hyderabad - ISSN : $978-81-7800-184-5$ (HB), 2009m

Peckham, S., Grell, G. A., McKean, S. A., Fast, J. D., and Gustafson, W. I. Annual Report CIRES/Univ. of Colorado \& NOAA/ESRL GSD, Boulder, CO

Regmi, Suman Kumar, Jayaraman Potty, PVS Raju and Itesh Dash: Performance evaluation of WRF model for Nepal, Workshop on Weather Forecasting and Flood Early Warning System in Nepal, 08th Apri 2011, KathmanduRosenfeld, D. and Silverman, BA., Results of On -Top Glaciogenic Cloud Seeding in Thailand, Part 1: The Demonstration Experiment, J. App. Meteor., 42,939-951, 2003.
Stone, R. H., Reno, NV; McGurty, B. M., Farber , R. J., Shaw, B. L., and Clarke, B.: Assessment of the San Joaquin Cloud Seeding Program using WRF based Sub Basin Quantitative Precipitation Forecasts as Formal Controls for Unseeded Precipitation: Preliminary Results obtained from the 2009 and 2010 Winter Seasons, 91st Americam Meteriological Society Meeting, 2011

Woodley, W. L., D. Rosenfeld and BA Silverman, Results of On -Top Glaciogenic Cloud Seeding in Thailand, Part 1: The Demonstration Experiment, J. App. Meteor., 42,920- 938, 2003. 